\title{
労苂保険診療に於ける全国調査について
}

\author{
福岡労災指定定院協会 溝 口博
}

\section{On the National Investigation for Clinics of Lobour Accidental Insurance \\ By}

H. Mizoguchi

Fukuoka Labour Accidental Hospital Association

労災保険は昭和 22 年 以来, 労働省管掌にて業務上 （除船員，公秝員）の受傷を対象とする一種の損害賠 償保険として発足した。その内容は医潦, 休業, 障害, 遺族，葬祭を包含する所謂完全保険である。此の点， 厚生省が管掌する社会保険（健保, 船員, 共済) 即ち 相互扶形保㰸とは自ら軌を異にする。然も外傷が主体 たる為，その殆どは外科医が取段うと云うも過言では ない。

労苂保険はその本質上，自由医潦及慣行料金を建前 そして発足した。然るに 24 年頃よりの保険経済の仜 機と共に先ず診療料金に於て漸次変貌し初め, 社保方 式の:采用が各地に行われて来た，但し単価に於ては各 地にて単価 18 円より 11,5 円の区々である。亦一部 の点数に特殊協定を加えた国保式とも云うべきものも ある。一方, 東京, 大阪の如き，件数の多い地方にて は昭和 26 年より指定病院による協会が誕生して, 独 自の単価, 点数を制定する形式が発生し, 他県にても, 做 5傾向があるが，基淮局との交渉には歓迎されて居 ない様である。大体に於て労災診潦の少い地方にては 社保がその鳃に適用せられて居る。亦所得率は社保の 如く $28 \%$ の適用を受けず新しい問題を投げて居る。 第十八条による制限は近来殆ど廃止され，査定は低単 価の地方は殆どなく，一高単価の地方に拈いて散見さ れる。

診療中の 病院に対する 調査は最近は漸次頻繁とな
り，或る地方にては毎月来院，患者及びカルテを照合 する例もある。特に治㾪の認定，入院の承認が中心で ある。各県毎に労災病院の設立も予想されて居るが此 等の問睤については診療担当者として労災保険の特質 を一層理解すると共に診潦能力の向上を考うべき事で ある。

指定病院協会は東京，大阪，兵庫，福岡にては活潑 に活動し，漸次全国にもその傾向あるも尚料金制定の 為のみの如き協会も存している。愛知県にては医師会 の一部門として取上げられている。東北, 北陸, 山陰 には協会の設立は殆どない。

社保との比較に於ては楽 $35 \%$ ，難 $15 \%$ で二年前の 全国調査に比し難とあるすのが $4 \%$ を増し特に国立病 院にて $24 \%$ と倍増して居る。

労災行政に対する希望は診療費千円未満の事業主負 担の廃止が最も多く，特に国立病院に著しい。次いで 事務の簡素化, 単価の值上げ, 所得率の引下げ, 診療 干渉の廃止, 全国統一化, 治澺の定義の再娭討, 後潦 法の拡大等である。

要するに労災保涘に於ける，診潦及料金は今日も尚 大きく動摇しつつあり，将来は国民皆保険を控えて大 変動が予測される。併し乍ら労災保険は最上の解決は 完全保険として, 休業, 障害等を含むため諸縣案, 迅 速治癒, 最高治療の外なきは明白であり, 賠償保健と しての本貿を把握する事にあると信ずる。

討 論

司会 久留米大学 宮 城 教 授

（座長挨搩）私が司会するのは不適当と思います が，提案された内藤博士が外遊されるために久席さ れましたので進行係をさせて頂きます。
只今講師の両先生のお話しでは, 労災法の改正に ついて䎧討中とのことであり，又最近の状㳯では労 災診潦の佨機であると言ら御意見むありましたやう 